\title{
Influence of Various Levels of Zinc and Sulphur on Storage Proteins and Protein Quality of Lentil (Lens culinaris) Varieties
}

\author{
Ajay Singh Chauhan ${ }^{1}$ and L. K. Mishra ${ }^{2 *}$ \\ ${ }^{1}$ Department of Biochemistry, College of Agriculture, NDUA\&T, Faizabad, U.P., India \\ ${ }^{2}$ Department of Basic Science and Humanities, College of Home Science, Central Agricultural \\ University, Tura, Meghalaya, India \\ *Corresponding author
}

\section{A B S T R A C T}

\begin{tabular}{|l|}
\hline K e y w o r d s \\
$\begin{array}{l}\text { Albumin, Globulin, } \\
\text { Storage proteins, } \\
\text { Tryptophan }\end{array}$ \\
\hline Article Info \\
\hline $\begin{array}{l}\text { Accepted: } \\
\text { 22 May } 2018 \\
\text { Available Online: } \\
\text { 10 June } 2018\end{array}$ \\
\hline
\end{tabular}

\section{Introduction}

India is the largest producer, consumer, importer and processor of pulses in the world. Pulses are the basic ingredient in the diets of a majority of the Indian population, as they provide a perfect mix of vegetarian protein component of high biological value when supplemented with cereals (Ali and Gupta, 2012). Lentil (Lens culinaris Medik.) is one of the most nutritious cool season food legumes and ranks next only to chickpea. It is grown throughout the northern and central India for grains. Besides its utilisation as a dal, whole or dehulled grains are also used in various other preparations. It is one of the prominent sources of vegetable protein in the IndoGangetic plain (IGP) region, essentially grown as a rainfed crop on the residual soil moisture of preceding crop (rice in-general) (Ali et al., 2012 and Joshi 1998).

Increased popularity of high yielding varieties (HYV), surging crop intensity, use of Sulphur/zinc free fertilizers and limited dependence on organic manures have depleted soil reserves of these vital plant nutrients causing emergence of their deficiency in most of the soils all over India in general and UP in particular. These nutrients play a vital role in biosynthesis of proteins and amino acids. The application of Sulphur and zinc fertilizers has shown significant effects on yield, uptake of 
nutrients and quality parameters in diverse crops. Research findings supporting the positive impact of zinc application have been reported earlier in wheat (Mishra, 2012), rice (Zeidan et al., 2010; Wei et al., 2012), maize (Potarzycki et al., 2009), cluster-bean (Meena et al., 2006), chickpea (Burman et al., 2013).

Likewise, application of Sulphur leading to improvement in yield and nutritional quality of cereal (Salvagiotti and Miralles, 2008) has been extensively reported while studies elucidating its role on pulses are scarce. Lentil is one of the principle rabi season crop cultivated in Indian subcontinent. It serves as an important source of protein for large section of population who use pulse as a principal component in their daily diet. The protein quality in Lentil has a major drawback as it is deficient in Sulphur containing essential amino acids like methionine. In addition, it also has very low levels of cysteine.

During seed development in pulses, enormous quantities of proteins are accumulated over a short period of time. These accumulated proteins are of less diversity butconstitute a major proportion of total seed protein in mature seeds. The globulin and albumins of pea, soybean, French bean, chickpea etc. have been extensively studied both qualitatively and quantitatively (Roy et al., 2010; Wang et al., 2008; Boye et al., 2010). But literature on lentil regarding this aspect of protein quality is rare. Therefore, keeping this in focus the present study was carried out.

\section{Materials and Methods}

\section{Lentil Samples}

Four varieties of lentil (Lens culinaris) viz: L - 4076, K - 75, NDL - 1 and DPL - 15 were obtained from Student's Instructional Farm, NDUA\&T, Kumarganj, Faizabad. The varieties were grown using standard agronomic practices in randomized block design having three replications. The $\mathrm{N}, \mathrm{P}$ and $\mathrm{K}$ were applied at the rate of 20:50:40 kg/ha, respectively. Soil samples were analysed for Sulphur by turbidity method and zinc by DTPA extractable method to ascertain their availability before and after conducting the experiments.

\section{Chemicals}

All chemicals used in the present investigation were of analytical grade and were purchased from Qualigen (India), SRL (India), or SigmaAldrich (USA).

\section{Total Protein Content}

The total protein content of the lentil seeds was measured using a modified version of the Bradford assay (Bradford, 1976). The dye reagent (Bio-Rad protein assay kit II, Bio-Rad Laboratory, Hercules, CA) was diluted in 1:4 with distilled water after which $5 \mathrm{~mL}$ of the diluted dye was added to $50 \mu \mathrm{L}$ of the lentil seed samples, mixed thoroughly and incubated in the dark for 5 minutes. For the blank tube $50 \mu \mathrm{L}$ of distilled water was used instead of the lentil seed sample. All samples were analysed in triplicates and the absorbance was then measured at 595nm using a UV-visible spectrophotometer (Genesys 10S UV-VIS spectrophotometer, Thermo Scientific, NY).

A standard curve was prepared using bovine serum albumin (BSA) in different concentrations and the protein content was expressed as percent dry weight.

\section{Quantitative determination of Protein Fractions}

Total protein of raw seed flour was extracted, based on the method outlined by Basha, Cherry, \& Young (1976). Proteins were 
purified by precipitation with $20 \%$ TCA and estimated according to Bradford assay (Bradford, 1976). The albumin and globulin fractions were separated, based on Murray (1979).

The protein fractions obtained were precipitated with TCA and re-dissolved in 0.2 $\mathrm{N} \mathrm{NaOH}$ and protein content was determined according to Bradford assay (Bradford, 1976) and expressed as $\mathrm{g} / 100 \mathrm{~g}$ protein.

\section{Determination of Amino acid composition}

Methionine content was determined according to the method of Horn et al., (1946). Lysine was determined according to the method of Felker et al., (1978) and the method proposed by Spies and Chamber (1949) was used to determine the tryptophan content. The results for amino acids were reported as and expressed as $\mathrm{g} / 100 \mathrm{~g}$ protein.

\section{Statistical analysis}

Entire biochemical analysis was repeated two times. Two runs were performed from each extraction and all assays were carried out in triplicates $(\mathrm{n}=12)$. Means, standard errors, and standard deviations were calculated from replicates using MS-Excel. The data were also analyzed for analysis of variance (ANOVA) using Statistical Analytical Software (SAS version 9.4; SAS Institute, Cary, NC).

\section{Results and Discussion}

The content of protein, tryptophan, lysine, methionine, globulin and albumin increased significantly with increasing levels of Sulphur upto $30 \mathrm{~kg} / \mathrm{ha}$ (Table 1 ). The increasing trend in the protein fractions may be attributed to the fact that Sulphur stimulates the biosynthesis of proteins and Sulphur containing amino acids which is reflected during the assay of the samples. Similar trend was observed for tryptophan and lysine also. Sulphur being an essential structural component of amino acids, co-enzymes involved in protein synthesis may have led to the increasing trend in protein and amino acids visible in the present investigation. Similar findings have been reported by Mishra et al., (2012), Raikwar et al., (2012) in wheat and barley respectively. Jamal et al., (2005) reported comparable results in soybean and Chiaiese et al., (2004) in chickpea.

Albumin content also increased significantly with increasing levels of Sulphur up to $30 \mathrm{Kg} / \mathrm{Ha}$. This may be due to high amino acid content particularly Sulphur containing amino acid methionine which is an important constituent of albumin protein fraction. On the contrary globulin fraction did not show any increase. The results are in accordance to the findings of Sharma and Sharma (2014); Sharma et al., (2013).

There was significant increase in all the parameters except protein, albumin and globulin content (table 1). Application of zinc significantly increased tryptophan content. Tryptophan is an essential amino acid containing aromatic ring and zinc in directly involved in the synthesis of this amino acid. Tryptophan is a precursor of auxin hormone and is therefore important in normal growth of the plants also.

The role of zinc as cofactors of several enzymes is well established. Similar findings were observed by Mishra (2012) in wheat, Wang \&Daun (2004) in Pisum sativum and Togay et al., (2004) in Phaseolus vulgaris L. A significant increase in lysine content was also observed by increasing zinc doses at $30 \mathrm{Kg} / \mathrm{ha}$, which in turn results in increased globulin content. Findings of Togay et al., (2004) in Phaseolus vulgaris L. support the results obtained in this investigation. 
Table.1 Biochemical composition of lentil as influenced by varieties, sulphur and zinc levels

\begin{tabular}{|l|l|l|l|l|l|l|}
\hline Treatment & $\begin{array}{l}\text { Protein } \\
(\% \mathrm{DW})\end{array}$ & $\begin{array}{l}\text { Tryptophan } \\
(\mathrm{g} / 100 \mathrm{~g} \\
\text { protein })\end{array}$ & $\begin{array}{l}\text { Lysine } \\
(\mathrm{g} / 100 \mathrm{~g} \\
\text { protein })\end{array}$ & $\begin{array}{l}\text { Methionine } \\
(\mathrm{g} / 100 \mathrm{~g} \\
\text { protein })\end{array}$ & $\begin{array}{l}\text { Albumin } \\
(\mathrm{g} / 100 \mathrm{~g} \\
\text { protein })\end{array}$ & $\begin{array}{l}\text { Globulin } \\
(\mathrm{g} / 100 \mathrm{~g} \\
\text { protein })\end{array}$ \\
\hline Variety & & & & & \\
\hline DPL -15 & 24.79 & 0.63 & 1.97 & 0.48 & 8.36 & 59.20 \\
\hline NDL -1 & 24.94 & 0.96 & 1.98 & 0.48 & 9.00 & 60.04 \\
\hline $\mathrm{K}-75$ & 26.16 & 0.99 & 1.97 & 0.54 & 9.34 & 60.06 \\
\hline $\mathrm{L}-4076$ & 24.48 & 0.60 & 1.93 & 0.48 & 8.12 & 59.45 \\
\hline CD at 5 \% & 0.51 & 0.02 & 0.04 & 0.01 & 0.17 & 1.28 \\
\hline Sulphur levels (in Kg/ha) & & & & & \\
\hline Control & 24.71 & 0.77 & 1.87 & 0.48 & 8.57 & 57.95 \\
\hline 10 & 25.05 & 0.80 & 1.97 & 0.49 & 8.65 & 59.70 \\
\hline 20 & 25.16 & 0.81 & 2.01 & 0.50 & 8.77 & 60.26 \\
\hline 30 & 25.45 & 0.82 & 2.02 & 0.51 & 8.83 & 60.84 \\
\hline CD at 5 \% & 0.51 & 0.01 & 0.04 & 0.01 & 0.16 & 1.27 \\
\hline Zinc levels $(\mathrm{Kg} / \mathrm{ha})$ & & & & & \\
\hline Control & 25.02 & 0.75 & 1.89 & 0.49 & 8.65 & 57.89 \\
\hline 10 & 25.04 & 0.81 & 1.96 & 0.49 & 8.71 & 60.30 \\
\hline 20 & 25.23 & 0.82 & 1.21 & 0.50 & 8.76 & 60.76 \\
\hline 30 & 25.08 & 0.81 & 1.99 & 0.48 & 8.70 & 59.80 \\
\hline CD at 5 \% & 0.51 & 0.02 & 0.03 & 0.01 & 0.17 & 1.28 \\
\hline
\end{tabular}

Table.2 Interaction of variety and sulphur on tryptophan (g/100g protein) in lentil varieties

\begin{tabular}{|l|l|l|l|l|}
\hline Zinc levels $(\mathrm{Kg} / \mathrm{ha})$ & $\mathrm{DPL}-15$ & $\mathrm{NDL}-1$ & $\mathrm{~K}-75$ & $\mathrm{~L}-4076$ \\
\hline Control & 0.63 & 0.65 & 1.05 & 0.63 \\
\hline 10 & 0.53 & 0.65 & 1.01 & 1.01 \\
\hline 20 & 0.63 & 0.65 & 1.08 & 0.89 \\
\hline 30 & 0.63 & 0.62 & 1.11 & 0.97 \\
\hline $\mathrm{CD}$ at $5 \%$ & & & 0.03 & \\
\hline
\end{tabular}

Table.3 Interaction of variety and sulphur on albumin $(\mathrm{g} / 100 \mathrm{~g}$ protein) in lentil varieties

\begin{tabular}{|l|l|l|l|l|}
\hline Sulphur levels $(\mathrm{Kg} / \mathrm{ha})$ & $\mathrm{DPL}-15$ & NDL -1 & $\mathrm{~K}-75$ & $\mathrm{~L}-4076$ \\
\hline Control & 8.09 & 8.78 & 9.33 & 8.10 \\
\hline 10 & 8.29 & 9.01 & 9.32 & 7.96 \\
\hline 20 & 8.09 & 9.44 & 9.45 & 8.10 \\
\hline 30 & 8.96 & 8.78 & 9.26 & 8.33 \\
\hline $\mathrm{CD}$ at 5\% & & 0.03 & \\
\hline
\end{tabular}

The variety $K-75$ proved significantly superior to rest of the three varieties (DPL $15, \mathrm{NDL}-1, \mathrm{~L}-4076$ ) with respect to all the protein quality parameters and storage proteins (Table - 1). The varietal difference among the three samples studied may be 
attributed to difference in genetic constitution. The results are in concordance to the findings reported by Mishra (2012), Wang and Daun (2004).

The interactive effect of zinc and varieties was significant and it was maximum in the variety $\mathrm{K}-75$ followed by NDL -1 with 30 , 40 and $20 \mathrm{Kg} \mathrm{Zn/ha} \mathrm{(table} \mathrm{2).} \mathrm{Similar}$ observations were also reported by Dwivedi et al., (2002).

The combined response of different levels of Sulphur and varieties were also noticed in albumin content (Table 3 ). The variety $\mathrm{K}-75$ performed better with $20 \mathrm{Kg} \mathrm{S} / \mathrm{ha}$. Our results are in accordance with the findings of Wang and Daun (2004).

The findings of the investigation indicate that lentil is a reasonable source of protein with the variety $K-75$ having the highest protein content. It is also concluded that application of sulphur and zinc fertilizers at $30 \mathrm{Kg} / \mathrm{ha}$ was the best dose that led to maximum protein content, albumin and globulin fractions. The application of zinc and sulphur fertilizer also led to increase in essential amino acids lysine, tryptophan and methionine reasonably well in all the varieties investigated. Overall it may be concluded that zinc and sulphur application @ 30Kg/ha can be used to improve both quantity and quality of varieties of lentil.

\section{Acknowledgement}

The university scholarship received by the first author is greatly acknowledged.

\section{References}

Ali, M., \& Gupta, S. (2012). Carrying capacity of Indian agriculture: pulse crops. Current Science, 874-881.

Ali, R.I., Awan, T. H., Ahmad, M. M., Saleem, U and Akhtar, M. (2012). Diversification of rice-based cropping systems to improve soil fertility, sustainable productivity and economics. Journal of Animal and Plant Sciences 22(1): 108-12.

Boye, J., Zare, F., \& Pletch, A. (2010). Pulse proteins: Processing, characterization, functional properties and applications in food and feed. Food research international, 43(2), 414-431.

Bradford, M.M., 1976. A rapid and sensitive method for the quantitation of microgram quantities of protein utilizing the principle of protein-dye binding. Analytical Biochemistry 72: 248-254.

Burman, U., Saini, M., \& Kumar, P. (2013). Effect of zinc oxide nanoparticles on growth and antioxidant system of chickpea seedlings. Toxicological \& Environmental Chemistry, 95(4), 605-612.

Chiaiese, P., Ohkama-Ohtsu, N., Molvig, L., Godfree, R., Dove, H., Hocart, C., and Tabe, L. M. (2004). Sulphur and nitrogen nutrition influence the response of chickpea seeds to an added, transgenic sink for organic sulphur. Journal of Experimental Botany, 55(404), 1889-1901.

Dwivedi. S. R., Singh, R.B. and Dwivedi, K.N. (2002). Effect of Sulphur and zinc nutrition on yield and quality of maize in typic ustrochrept soil of Kanpur. J. of Ind. Soc. of Soil Sci., 50 (1): 70-74.

Felker, C., Libanauskas, C. K., and Wainer, G. (1978). Estimation of lysine in foods. Crops Sci, 18(3), 480-490.

Horn, M. J., Jones, D. B., \& Blum, A. E. (1946). Colorimetric determination of methionine in proteins and foods. J. Biol. Chem, 166, 313-320.

Jamal, A., Fazli, I. S., Ahmad, S., Abdin, M. Z., \& Yun, S. J. (2005). Effect of sulphur and nitrogen application on growth characteristics, seed and oil yields of soybean cultivars. Korean Journal of Crop Science, 50(5), 340.

Joshi, P. K. (1998). Performance of grain legumes in the Indo-Gangetic Plain in residual effects of legumes in rice and wheat cropping systems of the IndoGangetic Plain. (In) Legumes in Rice and 
Wheat Cropping Systems of the IndoGangetic Plain. Kumarrao, J. V. D. K., Johansen, C. and Rego, T. J. (Eds). ICRISAT, Patancheru, Andhra Pradesh, pp $3-13$.

Kumar, A., Sharma, S., Sital, J. S., \& Singh, S. (2013). Effect of Sulfur and Nitrogen Nutrition on Storage Protein Quality in Mungbean [Vigna radiata (L.) Wilczek] Seeds. Indian Journal of Agricultural Biochemistry, 26(1), 86-91.

Meena, K. R., Dahama, A. K., \& Reager, M. L. (2006). Effect of Phosphorus and Zinc Fertilization on Growth and Quality of Clusterbean [Cyamopsis tetragonoloba (L.) Taub.].Annals of Agricultural Research, 27(3).

Mishra, L. K. (2012). Effect of phosphorus and zinc fertilization on biochemical composition of wheat. The Bioscan, 7(3), 445-449.

Potarzycki, J., \& Grzebisz, W. (2009). Effect of zinc foliar application on grain yield of maize and its yielding components. Plant Soil Environ, 55(12), 519-527.

Raikwar, R.S, and MIshra, L.K. (2012). Genetic architecture of yield and quality traits under problematic soils in Barley (Hordeum vulgare L.). International Journal of Agriculture, Environment and Biotechnology, 5:1, 13-17.

Roy, F., Boye, J. I., \& Simpson, B. K. (2010). Bioactive proteins and peptides in pulse crops: Pea, chickpea and lentil. Food research international, 43(2), 432-442.

Salvagiotti, F., \& Miralles, D. J. (2008). Radiation interception, biomass production and grain yield as affected by the interaction of nitrogen and sulfur fertilization in wheat. European Journal of Agronomy, 28(3), 282-290.

Sharma, A., \& Sharma, S. (2014). Effect of nitrogen and sulphur nutrition on yield parameters and protein composition in soybean [Glycine $\max$ (L.) Merrill]. Journal of Applied and Natural Science, 6(2), 402-408.

Spies, J. R., \& Chambers, D. C. (1949). Chemical determination of tryptophan in proteins. Analytical Chemistry,21(10), 1249-1266.

Togay, N., Ciftci, V., \& Togay, Y. (2004). The effects of zinc fertilization on yield and some yield components of dry bean (Phaseolus vulgaris L.). Asian Journal of Plant Sciences, 3(6), 701-704.

Wang, N., \& Daun, J. K. (2004). Effect of variety and crude protein content on nutrients and certain antinutrients in field peas (Pisum sativum). Journal of the Science of Food and Agriculture, 84(9), 1021-1029.

Wang, Z. H., Li, S. X., \& Malhi, S. (2008). Effects of fertilization and other agronomic measures on nutritional quality of crops. Journal of the Science of Food and Agriculture, 88(1), 7-23.

Wei, Y., Shohag, M. J. I., \& Yang, X. (2012). Biofortification and bioavailability of rice grain zinc as affected by different forms of foliar zinc fertilization. PloS one, 7(9), e45428.

Zeidan, M. S., Mohamed, M. F., \& Hamouda, H. A. (2010). Effect of foliar fertilization of $\mathrm{Fe}, \mathrm{Mn}$ and $\mathrm{Zn}$ on wheat yield and quality in low sandy soils fertility. World J. Agric. Sci, 6(6), 696-699.

\section{How to cite this article:}

Ajay Singh Chauhan and Mishra L. K. 2018. Influence of Various Levels of Zinc and Sulphur on Storage Proteins and Protein Quality of Lentil (Lens culinaris) Varieties. Int.J.Curr.Microbiol.App.Sci. 7(06): 3032-3037. doi: https://doi.org/10.20546/ijcmas.2018.706.356 